\title{
THE CORPORATE ENVIRONMENT OF MUNICIPALITIES
}

\section{PODNIKATELSKÉ PROSTY̌ EDÍ OBCÍ}

\section{Ing. Miroslava VAǴTíKOVÁ}

\section{InG. KaTEř InA MATUǴNSKÁ, PH.D.}

\author{
Katedra marketingu $\mid$ Department of Marketing \\ Obchodn Пpodnikatelská fakulta v Karviné $\quad$ School of Business Administration in Karviná \\ Slezská univerzita v Opav门| Silesian University in Opava \\ $\bowtie$ Univerzitní nám. 1934/3, 73340 Karviná, Czech Republic \\ E-mail:vastikova@opf.slu.cz,matusinska@opf.slu.cz.
}

\begin{abstract}
Annotation
This article presents outputs of a primary research aimed on the analysis of the corporate environment quality and standards of communication between the municipality and resident small and medium enterprises (SME). An inductive approach, theoretical discourse on the role of the municipality in creation of corporate environment that is based on marketing of municipalities and descriptive primary research with analysis of obtained results was used in the article. Municipalities were divided into two basic categories according to the number of inhabitants (up to 6 thousand inhabitants and over 6 thousand inhabitants) for the marketing research purposes.
\end{abstract}

\section{Key words}

corporate environment of a municipality, small and medium enterprises (SME), marketing research

\section{Anotace}

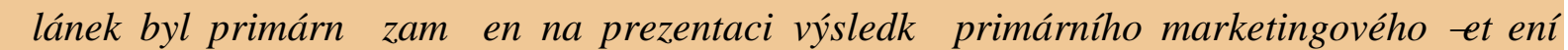
posuzujícího kvalitu podnikatelského prostŚedí obce a úrovn门 komunikace obce s organizacemi malého a stŚdního podnikání se sídlem na jejich území. Llánek obsahuje teoretické pojednání o úloze obcí ve vytváŚsní podnikatelského prostŚdí a analýzu získaných výsledkT z primárního getśsí. Pro potŚsy výzkumy byly obce rozd円eny do dvou kategorií dle pol tu obyvatel (obce do 6000 obyvatel a obce nad 6000 obyvatel).

\section{Klílová slova}

podnikatelské prostŚedí obce, malí a stŚední podnikatelé, marketingový výzkum

JEL classification: $M 31, H 40$

\section{Introduction}

Business in the field of small and medium enterprises is influenced by a whole range of factors. Some of them affect the entire SME sector without exception; particularly the economic environment where the phase of the economic cycle and the related purchasing power of inhabitants bring considerable difficulties to small and medium enterprises. Other factors that comprehensively affect the development of SMEs include the political and legislative environment. According to Kotler (2011), the ñmacro-environmentò of an enterprise also includes the demographic, cultural and social, natural or technological environment. In those environments, the level of the effect of the factors of the macro-environment differs and depends on the specifics of the industry where such enterprises operate. The function of the macro-environment presents unpredictable impacts of the surroundings. The macro-environment takes effect differently and continually. It is not possible to influence it, but only to adapt to this environment in a flexible way. (Kozel, 2006, p. 16) 
SMEs are not only influenced by their macro-environment, but also by the micro-environment. The marketing micro-environment (the sector of the company business activity or it could also be said micro-surroundings) includes circumstances, influences and situations which can be changed significantly by the company activity. (Jakubíková, 2008, p. 83) In this article, we will discuss one of many components of micro-environment: the place where the company is based, i.e. the municipality (the city). There is a rule that the image of a company is partially related to the municipality where it operates and vice versa: a desirable image of a municipality, including all its marketing activities, helps create the business environment and thus may also promote the business activity of the company.

\section{The Business Environment of the Municipality and Small and Medium Enterprises}

The enterprisers are said to be the persons who make a good thing of initiative and risk. (StaŔková, 2007, p. 1) The small and medium enterprises are regulated in the Czech Republic according to the small and medium enterprises support law. The liberal business environment, providing the same conditions to all business subjects, is the crucial presumption for prosperous business activities. (Praǵská, 2002, p. 58) Satisfactory definition of territorial marketing becomes increasingly complicated task also due to the fact that municipality/region represents much more complex unit than enterprise itself Common signs of territorial marketing can be thus found rather in used instruments, methods, concepts or common objectives. (Suchanek and Sed'a 2011) The business environment of a municipality is formed by three subsystems that mutually influence one another: (Vagíková and Janel ková 1999)

- The municipality itself.

- Organizations operating within the municipality.

- Historical and cultural factors, habits, traditions and customs of its inhabitants.

First and foremost, it is a municipality that co-creates the terms and conditions for the activity of businesses in its territory. From this point of view, the municipality is an enterprise as it shows the activity that creates a current or future gain. In spite of that, it is an organization where the allocation of resources is mainly executed through administrative orders. The municipality is a special type of organization particularly as it performs the functions of a local autonomy and public administration within the scope of the activity defined by the Act on Municipalities and some other regulations. Thus it is obvious that the municipality can choose neither the line, nor the place of business. This affects the mission of the organization (municipality) and represents a particular specific characteristic when creating business environment and an image of the organizational culture of the municipality.

On the other hand, some dominant businesses, large enterprises or companies that are the largest employer in the municipality may influence the municipality. If so, they indirectly affect the inhabitants and thus the atmosphere in the city or the municipality. Entrepreneurs create the gross domestic product of the municipality and participate in the economic and social environment, a factor of the municipalityô image. Small and Medium Enterprises represent $99.84 \%$ of all active companies in the Czech Republic. (The role of small and medium enterprises in society, 2013). Small and Medium Enterprises are usually in close relation in the region where they are located. Enterprisers live mostly in this region. Firstly they provide employment and economical benefits to this region, but also support many regional charitable and other events. (Veber, Srpová et al., 2005, p. 21). It is now well established that small and medium-sized enterprises (SMEs) play a vital role in the process of transition to a market economy. As the large firm sector, the prevalent form of organisation under central planning, underwent restructuring and decline, thousands of new SMEs took advantage of liberalised entry conditions and entered the market. They responded rapidly to systemic shocks, produced goods and services demanded by the population and, in the process, contributed to the generation of new jobs and incomes. (Gashi et al., 2014) 
Businesses thus affect the economic and social environment of the municipality both in the short and long term by creating the structure of the economy of the municipality (the region), its business culture, or the ñentrepreneurial spiritò of the locality.

The business environment also includes public organizations of municipalities and cities as a part of the social infrastructure that may attract entrepreneurs to the municipality and keep them there.

The business environment of the municipality is also formed by the historical and cultural factors, habits, traditions and customs of its inhabitants, which retroactively influences the business culture of the municipality as a whole and its image. Creating a balanced municipality, as it is usually defined by the vision of the municipality and its marketing strategy, cannot ensure the best management of the municipality in case that its activities remain limited to the city council and the municipal management. Therefore, the management of the municipality cannot do without cooperation $i$ partnership of all subjects representing the product of the municipality, and thus businesses.

\section{Primary Marketing Research}

The party ordering the research was interested in whether or not entrepreneurs are satisfied with the business environment in their municipality and with the level of marketing communication of the municipality where they are based. We determined a descriptive objective of the research: a description and characteristics of the aforementioned factors with regard to the size of the municipality, according to its population. The respondents were small and medium enterprises in the profit sector based in the Czech Republic. The total sample of respondents included 165 businesses based in 48 municipalities and cities in the Czech Republic. The interviewers were students of the School of Business Administration in Karviná. Random sampling was applied.

The set of 48 municipalities included municipalities of different sizes (as to the population). For a better comparison, we divided this set into two groups:

- A group of small municipalities with a population of up to 6 thousand $і ̈ 23$ municipalities. 47 respondents were based in this group $(28.49 \%)$.

- A group of large municipalities with a population exceeding 6 thousand - 25 municipalities. 118 respondents were based in this group $(71.51 \%)$.

These size criteria have been already used in realization of previous marketing research relating to marketing of municipalities.

At the same time, we determined the following three research hypotheses:

- H1: The respondents in the small municipality group will be more interested in the municipal activities than the respondents in the large municipality group.

- H2: The respondents in the large municipality group will evaluate the level of the municipal marketing communication higher than the respondents in the small municipality group.

- H3: The respondents' membership of the group of large municipalities or small municipalities has no effect on the evaluation of the business environment.

Nonparametric tests of hypotheses $\ddot{i}$ testing of the independence of the qualitative characters $\ddot{i}$ will be used for testing Hypothesis No. 1 and Hypothesis No. 3. The function in MS Excel CHITEST was used. The testing was proceeding at the relevancy level $\alpha=0.05$.

\section{Research Information Analysis}

As mentioned above, it is necessary to get the entrepreneurs involved in the activities of the municipality in order to make the municipality participate effectively in the establishment of the business environment.

The majority of the addressed respondents $(53.33 \%)$ are only interested in the activities in the municipality within their civic awareness, which is not very gratifying. $35.76 \%$ of respondents show 
an active interest and only 2 businesses are directly involved in the activities of their municipality. However, the most dismal is the finding that almost ten percent of all entrepreneurs $(9.7 \%)$ are not interested in the municipal activities at all.

We wanted to know whether the reality would differ for entrepreneurs based in a small municipality (up to 6 thousand inhabitants). It is obvious that according to the expectations, there was a greater interest of the entrepreneurs in the activity of the municipality in this group. 19 companies, i.e. 40.43 $\%$, were actively interested in the activity of the municipality. It was 40 companies (33.9\%) in the group of large municipalities. Only 3 businesses were not interested in the municipal activity (6.38 $\%$ ), while the proportion was $11.01 \%$ for businesses based in municipalities with more than 6 thousand inhabitants.

Based on the results of the statistical testing of H1 with the aim to map the effect of the size of the municipality on the interest of the entrepreneurs in its activity, there is no unambiguous relation between the defined characters; see Table 1. Therefore, the H1 hypothesis was dismissed.

Tab. 1: Testing of the independence of the qualitative characters ï the municipality size and the interest in the municipality activity

\begin{tabular}{|l|l|}
\hline \multirow{2}{*}{ Partial hypotheses } & $\begin{array}{l}\mathrm{H} 0 \text { : dependence between the municipality size and the interest in the } \\
\text { municipality activity }\end{array}$ \\
\cline { 2 - 2 } & $\begin{array}{l}\mathrm{H} 1 \text { : independence between the municipality size and the interest in the } \\
\text { municipality activity }\end{array}$ \\
\hline $\begin{array}{l}\text { p-value (result of CHITEST } \\
\text { in MS EXCEL) }\end{array}$ & 0.429788459 \\
\hline Hypotheses interpretation & $\begin{array}{l}\text { H0 is accepted: } p \text {-value }>\text { Uे }(0,05) \Rightarrow \text { independence between the size and the } \\
\text { interest in the municipality activity }\end{array}$ \\
\hline
\end{tabular}

Source: Authors' work

The following set of questions in our survey focused on the field of marketing communication of the municipality. The respondents were asked to assess the standard of the municipal website, the municipal promotional material and social public events organized by the municipality. They were asked to use a range of marks for the assessment, just like at school. The results of this survey in both groups are presented in Table 2. This question was not replied by 6 respondents, i.e. $3.64 \%$.

\section{Tab. 2: Selected marketing communication tools evaluation (all respondents)}

\begin{tabular}{|c|c|c|c|c|c|c|c|}
\hline \multirow[b]{2}{*}{ Marketing communication tools } & \multicolumn{5}{|c|}{ Evaluation } & \multirow{2}{*}{ Average } & \multirow[b]{2}{*}{$\%$} \\
\hline & 1 & 2 & 3 & 4 & 5 & & \\
\hline Web sites of the municipality & 54 & 58 & 25 & 8 & 2 & 1.95 & \multirow{3}{*}{89.09} \\
\hline Promotional materials of the municipality & 15 & 54 & 54 & 18 & 6 & 2.63 & \\
\hline $\begin{array}{l}\text { Social and public gatherings which are } \\
\text { arranged by the municipality }\end{array}$ & 41 & 56 & 37 & 11 & 2 & 2.16 & \\
\hline I donâ know, no interest & & & & 12 & & & 7.27 \\
\hline
\end{tabular}

The municipal websites had the best results, with the average mark of 1.95 . Social and public events organized by the municipality were second, with the average mark of 2.16. Promotional materials received the worst mark ï with the average mark of 2.63 .

In the group of businesses based in small municipalities, the order in the assessment of the communication mix tools changed a bit as compared with the total assessment of the respondents from both groups. Social and public events organized by the municipality received the average mark of 1.89. This evaluation meets the expectations as such events are usually the ñevents of the yearò in small municipalities and people pay a lot of attention to their preparation. It is also gratifying that the quality of websites was evaluated quite well, with the average mark of 2, which shows that even small municipalities have quality website administrators. Promotional materials received the worst evaluation again: 2.58. Table 5 shows the assessment of the selected elements of marketing 
communication by entrepreneurs based in large municipalities (over 6 thousand inhabitants). This question was not replied by 6 respondents, i.e. $5.09 \%$.

Respondents based in municipalities with more than 6 thousand inhabitants marked the websites higher than the respondents from the small municipality group, as expected. This confirms the estimate that larger cities and municipalities may allocate more budgetary resources and thus provide a better quality of processing. Our H2 hypothesis was thus confirmed. Promotional materials were placed on the second position (the small municipality group respondents evaluated those worse). The respondents from this group consider the quality of social public events organized by the municipality to be the worst, as compared with the evaluation by entrepreneurs from small municipalities.

When evaluating the overall level of the selected tools of marketing communication, our $\boldsymbol{H} 2$ hypothesis was not confirmed because the respondents from the group of municipalities with the population below 6 thousand evaluated the level of the selected marketing communication tools better.

In our opinion, the business environment of a municipality should also include whether or not the municipality provides links to the companies based in its territory on its website. Data imply that there is a lot to improve on the part of the municipalities, in both size categories. We believe that a better connection of the municipality with the businesses would bring benefits to both parties and also contribute to increasing mutual understanding. The availability of more comprehensive information on the municipal website should also be for the benefit of the municipality and should mean a practical step to the required business environment of a better quality for entrepreneurs.

We asked the respondents about the relationship of their organization with the municipality from the business activity aspect. The entire set of the addressed SMEs mainly relates to the municipalities as two independent subjects $(84.85 \%)$, i.e. 140 businesses. As for businesses in municipalities with more than 6 thousand inhabitants, this share is even higher $\ddot{i} 90.67 \% .10 .91 \%$ (18 companies) provide their products and services to the municipality on the basis of a business contract. This share is even higher in companies based in small municipalities where 10 companies, i.e. $27.21 \%$ deliver their products to the municipality. This fact confirms the presumption that the cooperation of the business sphere with the municipality and the quality of the business environment is better in small municipalities than in the large ones. Businesses, i.e. $1.82 \%$, cooperate with the municipality within the meaning of a joint business activity, out of which 2 businesses are based in the group of municipalities with less than 6 thousand inhabitants.

The survey also showed that one company, in the group of municipalities with a population exceeding 6 thousand, cooperates with the municipality on the basis of the PPP method.

The main objective of the survey was to examine how the addressed entrepreneurs evaluate the level of the business environment in their municipality. The positive finding of our survey is that a total of $67.88 \%$ of the addressed respondents are pleased with the business environment in their municipality. However, only $3.03 \%$, i.e. only 5 companies, consider those to be very good conditions for business. A total of 102 businesses are pleased, however, they see some areas for improvement. On the other hand, 34 companies $(20.60 \%)$ consider the business environment conditions in their municipality to be unsatisfactory. This opinion of about a fifth of all respondents does not only bring a topic for contemplation, but also a new foundation for the implementation of corrective measures taken in this area.

The share of satisfied respondents is a bit higher in the group of entrepreneurs based in small municipalities ï $70.22 \%$; however, only 2 companies are completely satisfied (4.26\%). Nevertheless, the share of unsatisfied entrepreneurs is also lower than in the set of all companies, i.e. $14.89 \%$. These results imply that the conditions for business on the part of the municipality are better in small municipalities. However, with regard to the low number of respondents and mainly the number of municipalities in both groups of the survey, we can only consider the informative value of those data to be indicative. 
The statistical testing of the determined research hypothesis $\ddot{i}$ H3 $\ddot{i}$ confirmed the presumption that the respondents' membership of the group of large or small municipalities has no effect on the evaluation of the business environment (Table 3). Thus, the H3 hypothesis was confirmed.

Tab. 3: Testing of the independence of the qualitative characters ï the municipality size and corporate environment

\begin{tabular}{|c|c|}
\hline \multirow[t]{2}{*}{ Partial hypotheses } & $\begin{array}{l}\text { H0: independence between the municipality size and the corporate } \\
\text { environment evaluation }\end{array}$ \\
\hline & $\begin{array}{l}\text { H1: dependence between the municipality size and the corporate environment } \\
\text { evaluation }\end{array}$ \\
\hline $\begin{array}{l}p \text {-value (result of CHITEST } \\
\text { in MS EXCEL) }\end{array}$ & 0.417920158 \\
\hline Hypotheses evaluation & $\begin{array}{l}\mathrm{H} 0 \text { is accepted: } p \text {-value }>\mathrm{U}(0,05) \Rightarrow \text { independence between the municipality } \\
\text { size and the corporate environment evaluation }\end{array}$ \\
\hline
\end{tabular}

Source: Authors' work

The evaluation of the business environment by respondents based in larger municipalities (cities) with more than 6 thousand inhabitants is considerably lower, in all types of responses than in the aforementioned group of respondents. We can only guess what the reasons of this phenomenon are: whether it is a higher concentration of the competitive environment, aggravated mutual communication of the business sector with the municipality or the lack of interest of both parties in dealing with this situation.

In the last free question, the respondents were asked to propose measures that the municipality could take, in their opinion, to improve the business environment. The responses included a whole range of various opinions, out of which we selected those that most respondents agreed upon:

- Focus on the possibilities of more intense cooperation between the municipality and the local businesses in potential joint projects.

- Place information about the companies in the territory of the municipality on its website for free.

- Organize joint meetings of entrepreneurs and the local government, or invite representatives of agencies such as CzechTrade, CzechInvest, etc.

There are strong relations between prosperous local economy creation and high quality municipality environment maintainance. These two elements are interactive and dependent on each other. The problems which influence the economy of municipalities and local small and medium enterprises are still urgent and substantial. It could be said as the common platform for mutual partnership.

We propose following steps:

- To create the programs of supporting services which give support to local employers in the form Âthe care afterñ This support is realized after investment which represents new jobs or the benefit for municipality (for example financing from the EU funds etc.).

- To create the Aspecial business panelñ on the web pages of municipalities. This panel should operate as the probing and interactive area to find out the enterprises' opinions relating to services of municipal council.

- The cooperation between two sides $\ddot{i}$ the enterprises and municipality in the area of the PR tools use in practice. For example it could be the video-clip creation showing the local tourist places of interest and local enterprises products and services. This presentation should be placed on the municipal web pages or municipal facebook.

- The common participation in Event marketing realization.

Conclusions

Our survey showed that there are many areas of improvement in establishing high-quality business environment in the municipalities for SMEs, not only on the part of the municipalities, but also on the 
part of the entrepreneurs who should get more interested in the activity of the municipality, namely in an active way, which $64.24 \%$ of all addressed respondents fail to do. The entrepreneurs critically assess the level of marketing communication of their municipality, with respect to the sample of selected tools. Against the presumptions, the level is better in the group of small municipalities of up to 6 thousand inhabitants than in the large municipality group (above 6 thousand inhabitants). The survey brought a positive finding: a total of $67.88 \%$ of all addressed entrepreneurs expressed their satisfaction with the business environment in their municipality. In the group of large municipalities, $66.95 \%$ of businesses were satisfied and in the group of small municipalities, $70.22 \%$ of the addressed respondents were satisfied with the business environment of their municipality.

It is obvious that the conditions for a ñ balanced municipalityò that would also fulfil the role of a key factor in the development of SMEs are rather created in small municipalities than the large ones. The results provide both a range of questions to discuss the causes of the present situation and, first and foremost, the possibilities of correcting the found out situation. We recommend to realize this type of marketing research repeatedly. It is possible to reach for the progress in the specific area of relationships in case of systematic monitoring and the resulting proposals implementation.

\section{References}

[1] GASHI, P., HASHI, I., PUGH, G., (2014). Export behaviour of SMEs in transition countries. Small Business Economics, vol. 42, iss. 2, pp. 407 - 435. ISSN 0921-898X. DOI 10.1007/s11187-013-9487-7.

[2] JAKUBÍKOVÁ, D., (2008). Strategický marketing. Praha: Grada Publishing. ISBN 978-80-247-2690-8.

[3] JANEL̦KOVÁ, L., VAǴTÍKOVÁ, M., (1999). Marketing $m$ П̧t a obcí. Praha: Grada Publishing. ISBN 807169-750-8.

[4] KOTLER, P., (2000). Marketing Management. Praha: Grada Publishing. ISBN 80-247-0016-6.

[5] KOZEL, R., et al., (2006). Moderní marketingový výzkum. Praha: Grada Publishing. ISBN 80-247-0966-X.

[6] PRAG̣SKÁ, L., JINDRA, J., et al., (2002). Obchodní podnikání ï Retail management. Praha: Management Press. ISBN 80-7261-059-7.

[7] Role malého a st Śedního podnikání ve spole nosti. ipodnikatel.cz., (2011) [online]. [cit. 2014-4-5]. Dostupné Z: <http://www.ipodnikatel.cz/O-podnikani-obecne/role-maleho-a-stredniho-podnikani-vespolecnosti.html>

[8] STAœKOVÁ, A., (2007). Podnikáme úspḥ̆̊ smalou firmou. Praha: C. H. Beck. ISBN 978-80-7179-926-9.

[9] SUCHACEK, J., SEńA, P., (2011). Territorial Marketing in the Czech Republic: Between PathDependency and Learning. In 10th International Conference of Liberec Economic Forum. Liberec: Technical University, pp. 439-447. ISBN 978-80-7372-755-0.

[10] VAǴTÍKOVÁ, M., (2011). Marketing obcí ï distan! ní studijní opora. Karviná. SU OPF. ISBN 978-807248-695-3.

[11] VEBER, J., SRPOVÁ, J., et al., (2005). Podnikání malé a stŚední firmy. Praha: Grada Publishing. ISBN 80-247-1069-2.

This paper is one of the research outputs of project OP VK No. CZ.1.07/2.2.00/28.0017 Project Ännovation of study programes at Silesian university in Opava, School of Business Administration in Karvina ̃̃ 